\title{
Bank Size, Risk-taking and Capital Regulation in Bangladesh
}

\author{
Mohammad M. RAHMAN ${ }^{*}$, Changjun ZHENG ${ }^{* *}$, Badar N. ASHRAF ${ }^{* * *}$
}

\begin{abstract}
This study examines the impact of bank size on bank regulatory capital ratios and risk-taking behavior using a panel dataset of 30 Bangladeshi commercial banks over the period 2008-2012. The relationship between bank regulatory capital ratios and bank risk-taking is also examined. For empirical analysis, generalized methods of moments (GMM) panel method are used to explore the relationships among bank size, regulatory capital ratios and risk-taking behavior. Empirical results show that large banks hold lower amount of capital and take higher level of risk. Findings also show a reverse relationship between bank capital levels and bank risk-taking; that is, banks holding higher levels of regulatory capital are significantly less risky. Findings of this study has important implications for the Bangladeshi government, policy makers, banking regulators and bank stakeholders regarding bank size, regulatory capital requirements and overall banking sector risk-taking behavior.
\end{abstract}

Keywords: Bank Size, Risk, Capital Regulation, Bank, Bangladesh

JEL Code Classification: F34, G17, G21, G32

UDC: 336.71(549.3)

\footnotetext{
School of Management, Huazhong University of Science and Technology, Wuhan, Hubei, P.R.China. Email: mmraiscu@gmail.com

** School of Management, Huazhong University of Science and Technology, Wuhan, Hubei, P.R.China.

Email: zhchjun@hust.edu.cn

${ }^{* * *}$ School of Management, Huazhong University of Science and Technology, Wuhan, Hubei, P.R.China. E-mail: badarfcma@gmail.com
}

Copyright (C, 2015 International Ataturk Alatoo University. 


\section{Introduction}

Many banks tend to merge with each other or tend to acquire other banks. An important outcome of mergers and acquisitions is the increase in bank size. Increase in bank size raises several important questions such as: 'Do the larger banks take higher risk as compared to the risk-taking of small banks?' and 'Do the larger banks hold higher levels of capital as compared to the capital levels of small banks?' Another linked question is 'What is the relationship between bank capitalization and bank risk-taking behavior?' Answers of these questions are important for the policy makers, as well as, for bank stakeholders. In this paper, we empirically address these questions using a panel dataset of 30 Bangladeshi commercial banks over the period 2008-2012. Specifically, we analyze the relationships among bank size, bank capital levels and bank risk-taking behavior.

Too-big-to-fail (TBTF) is an idea which suggests that the government will bail out a failing bank if the failing bank is big enough that its failure can have adverse impact on the whole economy of the country. In the short-run, a bank may have a tendency to take excessive risks if the bank is perceived to be TBTF. These aggressive risk-taking strategies by the larger banks are attributed to the moral hazard problems linked with TBTF policies of government and regulators (see details in Boyd et al., 2009). These moral hazard problems of TBTF also generate other problems. For example, Afzal and Mirza (2012) find that larger banks do not diversify their risks and continue their speedy growth by investing in few profitable sectors. For controlling excessive risk-taking by the larger banks, several arrangements of regulations have been proposed. For example, Boyd et al. (2009) and Walter (2009) propose to limit the size of the firms to address the issue of TBTF.

Does the bank size matter in Bangladesh's commercial banking sector? In this paper, we have an attempt to examine the effect of size on capital levels and risktaking of Bangladeshi banks including both private and state-owned commercial banks. Bank size can has a significant impact on bank capital levels and risk-taking behavior due to the relationship of bank size with investment opportunities, risk diversification and access to equity capital (Rime, 2001). For example, larger banks can operate with lower capital levels due to having an easy access to capital (equity) markets. Similarly, larger banks can easily carry out a large number of different activities and diversify their portfolios to reduce credit risk.

Basel I was introduced in 1988 to provide level playing field for international banking system. Basel II was introduced in 2006 to counter the weaknesses of Basel $I$ and to further improve the regulatory capital requirements. Occurrence of global financial crisis of 2007-2009 questioned the effectiveness of Basel I and II capital regulations as during crisis many banks failed due to weak capitalization positions. Basel III was introduced in 2010 to make up the shortcomings of Basel I and II. Bangladesh has implemented Basel-based capital regulation since 1996. According 
to this regulation, banks in Bangladesh have to maintain $10 \%$ capital adequacy ratio or Taka 4000 million which one is higher as a minimum capital.

Our paper is innovative in several aspects: First, our study is the first one to examine the relationship between bank size, capitalization and risk-taking behavior simultaneously for Bangladesh's commercial banks. Most of the previous studies in this direction have been done on the banking systems of Europe and/or USA. Very few studies have been done on the banking systems of Asian countries. Second, we use GMM panel method that is robust for endogeneity among variables.

The remainder of the paper is arranged as follows: Section 2 reviews existing literature briefly and states hypotheses to be tested. Section 3 reports data and defines variables used in the study. Section 4 presents econometric methodology. Section 5 reports empirical results and final Section 6 concludes the study and draws policy implications.

\section{Literature Review and Hypotheses development}

From long ago, banking research has focused on interplay between bank capitalization and bank risk-taking behavior. Equally important is the area of research that how banks of different size respond to capital regulations by adjusting capital ratios and risk. This section briefly reviews the related literature and states the hypotheses to be tested.

For the impact of higher regulatory capital requirements on bank risk-taking, extant banking literature is largely finds mixed conclusions. For instance, Koehn and Santomero (1980) examined the impact of higher capital adequacy ratios on portfolio risk of banks. They found ambiguous results for the average probability of failure due to a higher required capital adequacy ratio. But the dispersion of the probability of failure for intra-industry increases. They also concluded that either the regulation of bank capital through ratio constraint should be discontinued or for both asset composition and capital regulation should be imposed. Kim and Santomero (1988) investigated the impact of capital regulation on risk in banks. By using mean variance model they found that capital ratio regulation is not effective to control the insolvency risk of banks. As a solution to the problem they suggested to use risk weights under the risk-based capital and the risk weights are the restrictions for composition of assets, as a result the optimal portfolio of banks will be altered.

Furlong and Keeley (1989) examined theoretically the impact of capital regulation on bank asset portfolio risk. They found that higher capital requirements decrease the incentives of bank managers to raise the bank assets risk. High stringent capital regulation decreases the liability of deposit insurance system until there is an effort to contain asset risk and if the size is not reduced. They also observed that higher required capital is met by a value-maximizing bank and this is done by increasing additional capital. 
Jacques and Nigro (1997) found, by using a sample of US banks, that risk based capital requirements were effective in raising the capital ratios of the banks. They also found that risk based capital requirements reduce the portfolio risk of commercial banks. From their findings, it is seen that bank size has significant negative impact on changes in capital ratio and significant positive impact on changes in bank risk. Same conclusion is reached when Tier 1 capital is used instead of capital ratio. They concluded that banks which were unable to raise additional capital from external sources mainly met higher risk-based capital requirements by decreasing risky assets in portfolios.

Aggarwal and Jacques (1998) assessed the impact of Prompt Corrective Action on bank capital and risk by using U.S. commercial banks data over the period 19911993. They found that bank size has a significant negative impact on capital suggesting that larger banks hold lower amount of capital. On the other hand, they concluded that bank size has a negative impact on risk; larger banks take lower risk. They also found that changes in risk and changes in capital are negatively correlated when risk is measured by non performing loan to total assets ratio, but the relation is positive when risk is measured by risk weighted assets to total assets.

Ediz et al. (1998) examined the impact of risk-based capital requirements on U.K. bank behavior by using bank data over the period 1989-95. They concluded that UK banks responded to risk-based capital requirements by adjusting their portfolio risk, while banks didn't change their capital ratios much. They also found that banks met capital requirements by raising new capital rather than by alternating the loan composition in assets portfolio. Their findings largely suggest that capital regulation is an effective tool for reinforcing the stability of banks without disrupting banks choices of lending.

Blum (1999) examined whether risk-based capital requirements decrease bank risktaking in a dynamic theoretical model. He concluded that higher capital requirements will increase risk if cost of raising capital is excessively high. He also demonstrated that introduction of capital adequacy rules may not be a good idea if the regulators are interested to decrease the risk of insolvency.

Calem and Rob (1999) studied the impact of regulatory capital requirements on risk-taking behavior of banks. They found that there is a U-shaped relationship between bank capital and risk-taking which implies that when the capital of banks rises then the banks first take lower risk, and then higher risk. Due to deposit insurance premium surcharge, more risk is taken by undercapitalized banks. They found a positive relationship between capital and risk-taking for well-capitalized banks i.e. as the capital requirement increases risk taken by well-capitalized banks also increases.

Rime (2001) used data of Switzerland banks to examine the impact of regulatory capital requirements on bank risk-taking behavior. Their results indicated that 
banks increased their capital due to regulatory pressure. They also found that there is no significant relationship between regulatory pressure and risk. Banks having lower capital than minimum regulatory capital requirements want to raise capital adequacy ratio. It is concluded from their study that there is significant positive relationship between changes in capital ratio and changes in risk. For both alternative measures of capital (capital to risk-weighted assets and capital to total assets) they observed that bank size has significant negative impact on capital and has significant positive impact on risk.

Repullo (2002) analyzed the relationship among capital requirements, market power and risk taking. He used a dynamic model of imperfect competition where the banks have an option to invest in gambling or prudent assets. He found that the franchise values of banks are small if the margins of intermediation are small. There will be a gambling equilibrium if there is no regulation. He also found that capital requirements are effective in decreasing bank risk-taking in competitive banking industries.

González (2004) used a panel of 251 banks from 36 countries and analyzed the impact of bank regulation on bank risk-taking and charter values. They found that higher regulatory restrictions reduce bank charter values and increase incentives for banks to increase risk-taking. They largely found a negative relationship between the satiability of banking system and regulatory restrictions. They found that existence of deposit insurance in a country increases the bank charter values. They also showed that size has a positive impact on banks' credit risk measured by non performing loans to total loans. This implies that large banks take more risk.

Hussain and Hassan (2005) empirically examined the impact of capital requirements on credit risk-taking in developing countries using data from 11 developing countries. They found that such regulation did not raise the banks' capital ratio in developing countries. According to them, attention should be given to the environmental, cultural, business and legal issues in developing countries to design and implement capital regulations. However, they observed that such regulation did decrease the risk in banks. Evidence from their study has shown that financial development is adversely related with risk. It is also observed from their study that bank size has a significant negative impact on capital using both 3SLS and GMM estimators. On the other hand, banks size has a significant positive impact on risk when GMM estimator is used, while the impact is negative when $3 S L S$ estimator is used.

Altunbas et al. (2007) examined the relationships between capital, risk and efficiency by using banks from Europe for a period from 1992 to 2000 . They found a positive relationship between levels of capital and risk. Their study also shows that bank size has a significant negative impact on bank capital for all types of banks. On the other hand, bank size has a positive impact on bank risk for all types of banks except commercial banks for which relation is negative. 
Iwatsubo (2007) used a sample of Japanese banks and showed that the relationship between capital and risk is non-linear and direction of sign changes from positive to negative when franchise value decreases. They also found that when the banks are undercapitalized, capital requirements cannot prevent risk taking behavior of banks. This is because banks may issue more subordinated debts to meet their capital requirements. Banks are led to decrease their risky loans by government capital injections, where as banks can recover capital losses by the recapitalization through issuing subordinated debts.

Silva (2007) used seminal model developed by Blum (1999) to study the impact of capital regulation on risk taking. According to the findings of the study, risk is reduced by constant capital requirements. Monitoring and supervision is essential tool to reduce risk and to implement capital regulations.

Laeven and Levine (2008) empirically assessed the theories regarding bank ownership structures, bank industry regulations and bank risk taking. Specifically, they focused on the conflicts between owners and managers over bank risk-taking decisions. They found that main owner's control rights and bank risk-taking are positively linked; that is, bank risk-taking increases as the control rights of main shareholder increase. Their findings suggest that bank risk-taking also depends on the corporate governance structure of banks. They also found that bank size has a significant negative effect on bank risk-taking.

Roy (2008) examined that how banks adjusted their regulatory capital and riskweighted assets ratios in G-10 countries after the introduction of Basel I in 1988. He found that weakly capitalized banks increased their capital ratios in response to capital regulation, while capital regulation did not change the behavior of wellcapitalized U.S. banks. However, the risk-weighted assets were not modified by the weakly capitalized banks. According to the study, market discipline played a vital role in the capital build-up. Bank size has a negative impact on changes in capital ratios, which implies that banks with large size have easy access to capital market and by using a lower amount of capital they can operate. In addition, bank size has significant positive impact on changes in risk. It implies that large banks increase exposure to high risk.

Zhang et al. (2008) examined the impact of capital regulation on bank risk-taking using data of Chinese commercial banks. By using GMM dynamic estimator, they found a significant negative relation between changes in capital and changes in risk which implies that increment in capital ratio was effective to reduce the risk of commercial banks by implementing the capital adequacy regulation. They also concluded that bank size has a positive effect on changes in capital. This is because the larger banks have easy access to funds. They also found that bank size has a positive significant impact on bank risk confirming a TBTF effect.

Jokipii and Milne (2011) examined the relationship between adjustments in bank capital buffers and adjustments in portfolio risk in a dynamic panel setting. By using 
panel data of U.S. bank holding company and commercial banks over the period 1986-2008, their results indicate that the relationship between adjustments in capital buffers and adjustments in portfolio risk is a positive two way relationship. For bank size, by using single equation they found that size has a significant negative impact on capital buffer and positive impact on risk. Similar results are also found when they used simultaneous equations modeling.

Klomp and Haan (2012) used 200 banks from OECD countries covering a period of 2002-2008 to examine the impact of bank supervision and regulation on risk-taking. They found that bank supervision and regulation has strong impact on risk-taking decisions of high-risk banks. However, the impact is not significant for low-risk banks. Their findings also show that bank size has a positive impact on both capital and risk.

Afzal and Mirza (2012) used a sample of Pakistani banks and examined the relationship among bank size, risk and diversification. Specifically, they investigated whether banks with large size are better diversified. They found that in terms of size of credit portfolio the larger banks are more diversified. Both accounting and market based risk measures were used in the study.

From the literature we see that most of the studies are done on U.S. and European banks. For example, Aggarwal and Jacques (1998), Jokipii and Milne (2011), Laeven and Levine (2008), González (2004), Klomp and Haan (2012), Silva (2007), Furlong and Keeley (1989), Roy (2008), Jacques and Nigro (1997) worked on U.S. banks. On the other hands, Laeven and Levine (2008), González (2004), Klomp and Haan (2012), Roy (2008), Rime (2001), Ediz et al. (1998) worked on European banks. There are also some studies on Asian banks. For example, Iwatsubo (2005), Klomp and Haan (2012) worked on Japanese banks, Zhang et al. (2008) worked on Chinese banks, Lin et al. (2005) worked on Taiwanese banks, Afzal and Mirza (2012) worked on Pakistani banks, Laeven and Levine (2008), González (2004), Hussain and Hassan (2005) worked on Asian countries. As per our knowledge, there is no study on the relationship among bank size, risk-taking and capital for Bangladeshi banks. Both positive and negative relationship between bank size, risk-taking and capital are found in the literature. The present study is designed to observe the situation in Bangladesh. Based on the literature we have designed the following alternative hypotheses.

Hypothesis 1: There is a negative significant impact of capital on bank risk taking.

Hypothesis 2: There is a negative significant impact of risk on capital.

Hypothesis 3: Larger banks have a tendency to have lower amount of capital (i.e., there is a negative association between bank size and capital).

Hypothesis 4: Larger banks have a tendency to take higher risk (i.e., there is a positive relationship between bank size and risk taking). 


\section{Data and Variables}

\subsection{Data}

Data of bank-specific and macro-economic variables is used in empirical analysis. Banking sector of Bangladesh consists of 57 banks including 4 state-owned commercial banks, 39 private-owned commercial banks, 9 foreign-owned commercial banks and 5 state-owned specialized banks. Bank-specific income statement and balance sheet data over the period 2008-2012 is collected from the annual financial statements of the banks available on their websites. We exclude some banks which are very new or for which necessary data is not available. We also exclude 5 state-owned specialized banks as they do not run commercial business. Yearly macro-economic data is collected from the website of Bangladesh bank (http://www.bangladesh-bank.org) and World Development Indicators database of World Bank (http://data.worldbank.org).

\subsection{Variables Descriptions}

All the variables used in the study are described in this section. This section is divided into three sub-sections: Sub-section 3.2.1 describes the main variables, Sub-section 3.2.2 introduces bank-level control variables and Sub-section 3.2.3 describes the macroeconomic variables.

\subsubsection{Main Variables}

Bank Capital: The bank capital mainly includes funds from issuing shares and retained earnings. Two concepts of bank capital are mainly used in the literature: actual capital and regulatory capital. Actual capital is also known as physical capital and is composed of owner's equity. It is usually measured as the ratio of equity to total assets and also known as capital ratio. Regulatory capital is the capital measured on the base of bank risk and is maintained in accordance with the rules determined by the banking industry supervisor in a country. This capital is measured as the ratio of capital to risk-weighted assets and also known as riskbased capital ratio. As used by Shrieves and Dahl (1992), Altunbas et al. (2007), we refer capital ratio as the ratio of equity to total assets. Agency problem that is raised due to increase in equity can be dealt with directly by using capital ratio. This is because the capital ratio is considered as a standard measure of leverage. The second definition has been used by Jackes and Nigro (1997), Aggarwal and Jacques (1998), Ediz et al. (1998). In this paper, second definition of capital is used, because the second definition of capital is the requirement of Basel I, II and III.

Risk measures: Extant banking literature has used several variables to measure bank risk-taking. For example, bank credit risk is measured by the non-performing loans (NPL) to gross/total loans (NPLTL) ratio. Higher values of NPLTL ratio indicate that banks ex-ante took higher lending risk and, as a result, have accumulated expost higher bad loans on balance sheets (Zhang et al., 2013). This ratio is also used by Berger (1995), Shrieves and Dahl (1992). According to Zhang et al. (2013), 
market risk is measured by the interbank borrowing to total borrowing ratio where higher values of this ratio indicate that a bank highly relies on interbank borrowings. This suggests that banks are highly vulnerable to movements in market rates. Bank liquidity risk is measured by the liquid assets to total assets ratio. A high ratio indicates high liquidity and suggests a lower bank risk because banks can easily meet obligations when they become due for payments. Overall risk is measured by the ratio of loan loss reserve to NPL and this ratio indicates the ability of banks to absorb losses from NPLs (Zhang et al., 2013). Overall risk is also measured by the standard deviation of annual values of ROA and/or standard deviation of annual values of ROE. Higher values of these proxies indicate a higher level of overall bank risk. Another measure of bank risk is the ratio of risk weighted assets to total assets (RWATA). According to Avery and Berger (1991), RWATA ratio indicates bank risk-taking in risky assets. Z-score is a measure of bank default risk. $Z$-score equals the return on assets ratio (ROA) plus the capital asset ratio (CAR) divided by the standard deviation of return on assets ratio $(\sigma(R O A))$. Z-score measures the distance from insolvency. A high value shows high level of stability i.e. a high value of Z-score is associated with a lower level of bank insolvency risk. In this study, NPLTL and SROA are used as proxy for credit risk and overall risk, respectively.

Bank Size: Bank size (SIZE) variable is used to proxy for bank size and is measured as the natural logarithm of annual bank total assets. SIZE variable is included in both risk and capital equations to consider the size effects. SIZE is considered as an important determinant of bank risk-taking and capital. SIZE has an impact on various activities of banks including investing opportunities, portfolio diversification, reputation and access to equity capital (Zhang et al., 2008). As the large banks have easy access to equity capital market, thus we expect a large bank will have lower capital ratio than smaller banks. In addition, as large banks can carry out a large number of different activities, so they can diversify their portfolio, and, hence credit risk will be decreased (Roy, 2008). We assume large banks take more overall risk.

\subsubsection{Bank specific control variables}

Three bank-level control variables, bank earnings, liquidity and deposit base, are included in empirical models to control for other bank attributes that are likely to affect bank capitalization and risk-taking decisions. Brief definitions of these banklevel control variables are as follow:

Earning Level: Operating income is considered as an important source of capital (Zhang et al., 2008). Internal funds are one of the important sources to increase capital (Berger, 1995). Banks can increase capital by not paying or by paying lower amount of dividends and retaining surplus profits (Ashraf et al., 2015). Therefore, we include the return on assets (ROA) as an explanatory variable in the capital 
equation to control for the ability of profitable banks to accumulate capital through retained earnings.

Liquidity: A portion of total assets represents loans and advances. We include the ratio of total loans to total assets (TLTA) in both capital and risk equations. High level of loans and advances indicates high level of liquidity and corresponds to higher investment in risk-weighted assets. As a result, it will lead the banks to a high level of credit risk and there is a need for higher level of capital (Roy, 2008; Berger, 1995).

Deposit ratio: Bank risk is affected by deposits which include savings, time deposits and demand deposits. We include the total deposits to total assets ratio (TDTA) as a proxy for deposit ratio. As deposits are insured, a higher deposit ratio raises moral hazard of banks to fund in risky investments. Meanwhile, a high level of deposit ratio indicates a high level of leverage risk. We expect a positive relationship between deposit ratio and bank risk taking.

\subsubsection{Macroeconomic variables}

Several recent studies have shown that country-level factors are important for bank-level practices (Ashraf and Zheng, 2015; Houston et al., 2010; Kanagaretnam et al., 2014; Zheng and Ashraf, 2014), therefore we include following variables in our empirical models to control for macro-economic environment of the country.

Growth in real GDP: National level of GDP growth may affect the banks' capital and credit risk choices by affecting the overall loan demand in the economy (Ayuso et al., 2004; Jiménez and Saurina, 2006). Therefore, we include growth in real GDP (GGDP) variable in both capital and risk equations to control for GDP growth effects.

Inflation: We also include inflation in both capital and risk equations to consider the changes in macro-economic condition of the country that also influences the relationship between risk and capital. Hussain and Hassan (2005) have shown that there is a significant negative impact of inflation on capital. On the other hand, there is a positive impact of inflation on risk. We use annual inflation rate (INFR) as a proxy for inflation.

The list of variables with their acronym is stated in Table 1 and the expected sign of relationships among variables are depicted in Table 2. 
Table 1: Description of variables

\begin{tabular}{|c|c|c|c|}
\hline \multicolumn{2}{|c|}{ Variables } & Acronym & Definition \\
\hline \multicolumn{2}{|c|}{ Capital } & CAP & Ratio of capital to risk weighted assets \\
\hline & Credit Risk & NPLTL & Ratio of non-performing loan to total loan \\
\hline & Overall Risk & SROA & Standard deviation of return on assets \\
\hline \multicolumn{2}{|c|}{ Bank Size } & SIZE & Natural logarithm of total assets \\
\hline \multicolumn{4}{|c|}{ Bank Internal Control Variable } \\
\hline \multicolumn{2}{|c|}{ Earning Level } & ROA & Return on assets \\
\hline \multicolumn{2}{|c|}{ Liquidity } & TLTA & Ratio of loans and advances to total assets \\
\hline \multicolumn{2}{|c|}{ Deposit Ratio } & TDTA & Ratio of total deposits to total assets \\
\hline \multicolumn{4}{|c|}{ Macro-economic variable } \\
\hline \multirow{2}{*}{\multicolumn{2}{|c|}{$\begin{array}{l}\text { GDP growth } \\
\text { Inflation }\end{array}$}} & GGDP & Annual growth in real gross domestic products \\
\hline & & INFR & Annual inflation rate \\
\hline
\end{tabular}

Table 2: Expected sign of the impacts of variables on risk and capital

\begin{tabular}{lll}
\hline Variables & Capital & Risk \\
\hline Bank size & - & + \\
Earning Level & + & - \\
Liquidity & - & + \\
Deposit ratio & & + \\
GDP growth & + & + \\
Inflation & - & \\
\hline
\end{tabular}

\section{Econometric Model}

We use simultaneous equation model developed by Shrieves and Dahl (1992) to examine the relationship among bank size, risk-taking and capital. But, in our study, we examine the relationship between capital levels and risk levels rather than relationship between changes in risk and changes in capital. This is because we are limited by the length of period for data. As the risk and capital are correlated, they are endogenous variables and in the simultaneous equations they are explanatory variables to one another. We specify following set of simultaneous equations and use panel GMM estimator to estimate these equations.

$$
\begin{aligned}
& \text { CAP }_{i t}=\alpha+\beta_{1} \text { RISK }_{i t}+\beta_{2} \text { SIZE }_{i t}+\beta_{3} \text { ROA }_{i t}+\beta_{4} \text { TLTA }_{i t}+\beta_{5} \text { GGDP }_{t}+\beta_{6} \text { INFR }_{t}+\varepsilon_{i t} \\
& \text { RISK }_{i t}=\alpha+\beta_{1} \text { CAP }_{i t}+\beta_{2} \text { SIZE }_{i t}+\beta_{3} \text { TLTA }_{i t}+\beta_{4} \text { TDTA }_{i t}+\beta_{5} G_{\text {GDP }}+\beta_{6} I_{\text {INFR }}+\varepsilon_{i t}
\end{aligned}
$$

Where the subscript $\mathrm{i}$ indicates the banks, and $\mathrm{t}$ indicates the time. $\varepsilon_{\text {it }}$ indicates error term. To account for endogeneity and simultaneity between capital and risk, RISK and CAPITAL are included in the capital and risk equations, respectively. Bank capital is dependent variable in equation (1) and bank risk is dependent variable in equation (2). 


\section{Empirical Result}

This section reports the empirical results derived from the simultaneous equation model specified above where capital and risk are the endogenous variables in risk and capital equations, respectively. The GMM estimation has been used for the endogeneity problem. In this study, the balanced panel model has been used. In modeling panel data with a long-time dimension, it is a challenge that the variables are likely to be non-stationary. There are only five years time dimension and by conducting unit root tests the nature of stationarity of data has been tested and found that the data are non-stationary. This is may be due to the short term panel data. This section is divided into three parts. Part 1 shows descriptive statistics, part 2 explains the correlation among the variables and part 3 describes the regression analysis by using GMM estimator.

\subsection{Descriptive Statistics}

Descriptive statistics of all variables are presented in the Table 3. Descriptive statistics is reported in three groups: for full sample in first four columns, for large banks in next four columns and for small banks in last four columns. A bank is considered as large if it has more assets than the average assets of all banks included in the study.

\section{Table 3: Descriptive statistics of the variables used in the study}

\begin{tabular}{lcccccccccccc}
\hline & \multicolumn{4}{c}{ All Banks } & \multicolumn{4}{c}{ Large Banks } & \multicolumn{4}{c}{ Small Banks } \\
& Mean & Max & Min & S.D. & Mean & Max & Min & S.D. & Mean & Max & Min & S.D. \\
\hline CAP & 11.73 & 30.75 & -6 & 3.60 & 10.67 & 14.71 & -6 & 2.99 & 12.42 & 30.75 & 8.11 & 3.81 \\
NPLTL & 4.18 & 25.3 & 0.44 & 3.82 & 5.69 & 25.3 & 1.18 & 5.41 & 3.20 & 9.73 & 0.44 & 1.67 \\
SROA & 0.77 & 2.68 & 0.27 & 0.50 & 1.05 & 2.68 & 0.46 & 0.70 & 0.59 & 0.744 & 0.277 & 0.13 \\
SIZE & 11.54 & 13.28 & 10.34 & 0.60 & 11.99 & 13.28 & 11.05 & 0.51 & 11.24 & 12.06 & 10.34 & 0.45 \\
ROA & 1.57 & 3.74 & -4.92 & 1.04 & 1.34 & 3.54 & -4.92 & 1.38 & 1.72 & 3.74 & 0.21 & 0.72 \\
TLTA & 67.58 & 90.14 & 32.41 & 8.89 & 67.82 & 90.14 & 48.75 & 8.38 & 67.42 & 81.92 & 32.41 & 9.26 \\
DEPTA & 80.38 & 100 & 61.07 & 5.75 & 81.61 & 100 & 72.30 & 4.95 & 79.59 & 89.41 & 61.08 & 6.12 \\
GGDP & 6.23 & 6.7 & 5.74 & 0.31 & 6.23 & 6.7 & 5.74 & 0.30 & 6.22 & 6.7 & 5.74 & 0.32 \\
INFR & 8.54 & 10.62 & 6.66 & 1.46 & 8.54 & 10.62 & 6.66 & 1.44 & 8.54 & 10.62 & 6.66 & 1.48 \\
\hline
\end{tabular}

Note: A bank is considered as large if it's assets size is more than the average asset size of all banks in sample, otherwise the bank is considered as small bank. Max= Maximum, Min= Minimum, S.D= Standard Deviation.

From the Table 3 , it is seen that average CAP for all banks is $11.73 \%$ with a standard deviation of $3.60 \%$. The maximum CAP is $30.75 \%$ and minimum is $-6 \%$ when all banks are considered. Average CAP is $10.67 \%$ for large banks with a standard deviation of $2.99 \%$, whereas average CAP is $12.42 \%$ for small banks with a standard deviation of $3.81 \%$. The CAP for large banks ranges from a maximum $14.7 \%$ to a minimum $-6 \%$. On the other hand, the CAP for small banks ranges from a maximum $30.75 \%$ to a minimum $8.11 \%$. On an average, the CAP is higher for small banks than large banks. For both large and small banks, the average CAP is more than the minimum regulatory capital of $10 \%$. 
Average credit risk as measured by NPLTL is $4.18 \%, 5.66 \%$ and $3.20 \%$ for all banks, large banks and small banks, respectively. Average overall risk as measured by SROA is $0.77 \%, 1.05 \%$ and $0.59 \%$ for all banks, large banks and small banks, respectively. It is seen from the Table 3 that large banks take more credit and overall risk than that of small banks. Average earning level as measured by ROA is $1.57 \%, 1.34 \%$ and $1.72 \%$ for all banks, large banks and small banks, respectively. On average, small banks perform better than large banks. The average liquidity measured by TLTA is $67.82 \%$ for large banks and $67.42 \%$ for small banks. This implies that large banks are more liquid than small banks. DEPTA of large banks is more than that of small banks. Average deposit ratio is $81.61 \%$ for large banks. On the other hand, average deposit ratio for small banks is $79.59 \%$. The average GGDP and INFR are $6.23 \%$ and $8.54 \%$ respectively for the period under study. The GGDP ranges from a maximum $6.7 \%$ to a minimum $5.74 \%$. The INFR ranges from a maximum $10.62 \%$ to a minimum $6.66 \%$.

\subsection{Correlation Analysis}

Pearson's correlations coefficients between the variables are presented in Table 4. The primary concern of the study is to observe the relationship among bank size, risk and regulatory capital of banks. Other bank-level and country-level macroeconomic variables are used as control variables. From the Table 4, it is clear that regulatory capital is negatively related with the credit risk as proxied by NPLTL and with the overall risk as proxied by SROA. The relations are significant at $1 \%$ level of significance.

Table 4: Pearson's Correlation among the variables

\begin{tabular}{lccccccccc}
\hline & CAP & NPLTL & SROA & ROA & SIZE & TLTA & DEPTA & INFR & GGDP \\
\hline CAP & 1.000 & & & & & & & & \\
NPLTL & $-0.423^{* * *}$ & 1.000 & & & & & & & \\
SROA & $-0.325^{* * *}$ & $0.764^{* * *}$ & 1.000 & & & & & & \\
ROA & $0.489^{* * *}$ & $-0.642^{* * *}$ & $-0.344^{* * *}$ & 1.000 & & & & & \\
SIZE & $-0.433^{* * *}$ & $0.494^{* * *}$ & $0.510^{* * *}$ & $-0.439^{* * *}$ & 1.000 & & & & \\
TLTA & $-0.350^{* * *}$ & $-0.368^{* * *}$ & $-0.281^{* * *}$ & $0.157^{*}$ & $-0.141^{*}$ & 1.000 & & & \\
DEPTA & $-0.400^{* * *}$ & -0.096 & -0.030 & -0.028 & 0.013 & $0.333^{* * *}$ & 1.000 & & \\
INFR & -0.019 & $0.192^{* *}$ & 0.013 & $-0.379^{* * *}$ & $0.161^{*}$ & -0.107 & $-0.194^{* *}$ & 1.000 & \\
GGDP & 0.040 & $0.249^{* * *}$ & 0.040 & $-0.436^{* * *}$ & 0.117 & $-0.219^{* *}$ & -0.085 & $0.728^{* * *}$ & 1.000 \\
\hline${ }^{* * *},{ }^{* *},{ }^{*}$ Correlation is significant at $1 \%, 5 \%$, and $10 \%$ respectively & & & &
\end{tabular}

The regulatory capital is positively related with bank earnings as proxied by ROA. This implies that banks with better performance hold more capital. The relation between earning level and risk (proxied by NPLTL and SROA) is negative and significant at $1 \%$ level of significance for both NPLTL and SROA. The negative relation demonstrates that the banks with higher earnings levels take lower levels of risk. Bank size (SIZE) is negatively related with CAP and positively related with risk (NPLTL and SROA). All these relations are significant at $1 \%$ level of significance. The negative relation between SIZE and CAP implies that large banks have lower 
levels of regulatory capital, whereas small banks hold higher levels of regulatory capital. The positive relation between risk and SIZE demonstrates that larger banks take higher risk and smaller banks take lower risk. It is also seen from Table 4 that liquidity (proxied by TLTA) is negatively related with CAP, NPLTL and SROA. The relations are significant at $1 \%$ level. The negative relations state that liquid banks hold lower amount of capital and take lower level of risk.

Deposit ratio has a significant negative relation with CAP. It means that banks with higher deposit ratio hold lower level of capital. Deposit ratio has negative relation with risk, but the relation is not statistically significant. The negative relation implies that banks with lower deposit ratio take more risk. Inflation has negative relation with CAP and positive relative with risk. During high inflation banks hold lower amount of capital and take more risk. GGDP has a positive relation with CAP, NPLTL and SROA. During high growth in real GDP, banks hold more capital and take higher risk. Some relationships are ambiguous and some sign of relationships are also ambiguous. Therefore, we run multivariate regression analysis.

\subsection{Regression Analysis}

System GMM panel estimator, developed by Arellano and Bover (1995) and Blundell and Bond (2000), is used to estimate the Equations 1 and 2. System GMM estimator takes into account the endogeneity problems and serial correlation. Estimated results from GMM estimator are shown in Tables 5 and 6. Main variables are bank size (SIZE), regulatory capital ratios (CAP) and risk (NPLTL and SROA). The main concern of the study is to see the relationship among the bank size, regulatory capital ratios and risk. Related bank-level and macroeconomic control variables are also included. Results from regression analyses are displayed in two parts. Part 5.3.1 discusses the impact of bank size and risk on capital. Part 5.3.2 explains the impact of bank size and capital on risk.

\subsubsection{Impact of bank size and risk on bank capital}

Equation 1 is estimated with system GMM estimator and results are reported in Table 5. Negative and significant (at $1 \%$ level) coefficients on NPLTL and SROA variables in Models 1 and 2, respectively, show that there is a reverse relationship between bank capital and risk-taking. This result is consist with the findings of Furlong and Keeley (1989), Jacques and Nigro (1997), Ediz et al. (1998), Repullo (2002), Hussain and Hassan (2005), Silva (2007), Zhang et al. (2008), but opposite to the results of Blum (1999), Rime (2001), González (2004), Altunbas et al. (2007), Jokipii and Milne (2011). As t-values are significant for both models, the null hypothesis of no significant association is rejected. The negative relation implies that if banks want to decrease risk by $1 \%$ then the level of capital has to be increased by $0.30 \%$ for NPLTL and $1.31 \%$ for SROA.

SIZE variable enters negative and significant in both Models and show that bank size has a significant negative impact on capital. This result is consistent with the 
findings of Jacques and Nigro (1997), Aggarwal and Jacques (1998), Rime (2001), Altunbas et al. (2007), Roy (2008), Jokipii and Milne (2011), but is opposite to the findings of Zhang et al. (2008), Klomp and Haan (2012). Negative relation indicates that large banks maintain lower level of capital. As t-values are significant for both models, the null hypothesis is rejected and alternative hypothesis of significant negative association between bank size and capital is accepted.

\section{Table 5: Impact of risk on capital}

\begin{tabular}{lcc}
\hline Variables & Model 1 & Model 2 \\
& RISK=NPLTL & RISK=SROA \\
\hline C & $23.6129^{* *}(1.99)$ & $20.2583^{*}(1.65)$ \\
NPLTL & $-0.3061^{* * *}(-3.88)$ & \\
SROA & & $-1.3102^{* * *}(-2.65)$ \\
SIZE & $-0.9838^{*}(-1.90)$ & $-0.9662^{*}(-1.74)$ \\
ROA & $1.1977^{* * *}(2.93)$ & $1.6893^{* * *}(3.93)$ \\
TLTA & $-0.1799^{* * *}(-3.32)$ & $-0.1560^{* * *}(-2.82)$ \\
GGDP & $1.7453(1.43)$ & $1.8264(1.44)$ \\
INFR & $0.0039(0.02)$ & $-0.0019(-0.008)$ \\
CAP(-1) & $-0.2238^{* * *}(-2.77)$ & $-0.2168^{* * *}(-2.72)$ \\
Adjusted R & 58.02 & 54.99 \\
Hausman Test, F(p-value) & $13.1699(0.000)$ & $12.3751(0.000)$ \\
Sargan test (p-value) & 0.397 & 0.421 \\
Serial correlation test $(p-v a l u e)$ & 0.000 & 0.000 \\
Observations & 150 & 150 \\
Number of banks & 30 & 30 \\
\hline
\end{tabular}

Notes: The table shows the empirical results from GMM panel estimator. Dependent variable is capital in both Models. ${ }^{* * *},{ }^{* *}$ and ${ }^{*}$ indicate significance at the $1 \%, 5 \%$ and $10 \%$, respectively. For Hausman test $p$-values are in parentheses. $t$-statistics are shown in parentheses.

Control variables also enter in expected directions. For example, results show a positive and significant association between bank earnings and capital, and suggest that profitable banks retain more profits to increase capital. Similarly, negative and significant coefficients on TLTA variable show that more liquid banks hold lower levels of capital. GDP growth and inflation variables have positive impact on capital but these relations are not statistically significant. Lagged-capital variable enters negative and significant in both Models. This negative sign indicates that banks with a lower capital ratio in the last period will raise their capital in the current period.

From the adjusted $\mathrm{R}$-square it can be concluded that $58.02 \%$ and $54.99 \%$ variation in capital are explained by the Models 1 and 2, respectively. The p-value of Hausman Test for Models 1 and 2 is 0.000 (significant at 1\% level) implying that risk and capital are simultaneously determined. Sargan test for Model 1 and 2 is not significant and null hypothesis that over identification restrictions are valid cannot be rejected. Serial correlation test reject the null hypothesis of no serial correlation. 


\subsubsection{Impact of bank size and capital on bank risk}

Equation 2 is estimated with system GMM estimator and results are reported in Table 6. Negative and significant (at $1 \%$ level) coefficients on CAP variable in both Models show that there is a negative relationship between bank risk-taking and capital. These results support the findings of Furlong and Keeley (1989), Jacques and Nigro (1997), Ediz et al. (1998), Repullo (2002), Hussain and Hassan (2005), Silva (2007), Zhang et al. (2008), but are opposite to the results of Blum (1999), Rime (2001), González (2004), Altunbas et al. (2007), Jokipii and Milne (2011). The negative relation indicates that if banks increase capital by $1 \%$ then credit risk (proxied by NPLTL) decreases by $0.61 \%$ and overall risk (proxied by SROA) decreases by $0.05 \%$. As t-values are significant for both models, the null hypothesis of no significant impact of capital on risk is rejected and alternative hypothesis is accepted.

\section{Table 6: Impact of capital on risk}

\begin{tabular}{lcc}
\hline Variables & Model 1 & Model 2 \\
& RISK=NPLTL & RISK=SROA \\
\hline C & $10.4793(1.26)$ & $-0.0177(-0.02)$ \\
CAP & $-0.6059^{* * *}(-4.88)$ & $-0.0456^{* * *}(-3.19)$ \\
SIZE & $1.3207^{* * *(3.50)}$ & $0.2846^{* * *}(3.97)$ \\
TLTA & $-0.2061^{* * *}(-6.17)$ & $-0.0191^{* * *}(-4.30)$ \\
DEPTA & $-0.1376^{* * *}((-2.67)$ & $-0.0059(-0.82)$ \\
GGDP & $1.9228^{* *}(2.16)$ & $0.0204(0.11)$ \\
INFR & $-0.1638(-0.67)$ & $-0.0359(-0.94)$ \\
NPLTL(-1) & $-0.3589^{* * *}(-3.12)$ & \\
SROA(-1) & & $-0.8093^{* * *}(-7.65)$ \\
Adjusted R & 54.77 & 37.36 \\
Hausman Test, F(p-value) & $7.3458(0.000)$ & $13.8444(0.000)$ \\
Sargan test (p-value) & 0.286 & 0.352 \\
Serial correlation test $(p-v a l u e)$ & 0.000 & 0.000 \\
Observations & 150 & 150 \\
Number of banks & 30 & 30 \\
\hline
\end{tabular}

Notes: The table shows the empirical results from GMM panel estimator. Dependent variable is risk for both models. ${ }^{* *}, * *$ and $*$ indicate significance at the $1 \%, 5 \%$ and $10 \%$ respectively. For Hausman test $\mathrm{p}$-values are in parentheses. t-statistics are shown in parentheses.

SIZE variable enters positive and significant in both Models and show that as the bank size increases, the banks take higher risk. This result supports the findings of Jacques and Nigro (1997), Rime (2001), González (2004), Hussain and Hassan (2005), Altunbas et al. (2007), Roy (2008), Zhang et al. (2008), Jokipii and Milne (2011), Klomp and Haan (2012), but is opposite to the findings of Aggarwal and Jacques (1998), Laeven and Levine (2008).

For the results of control variables, liquidity has a significant negative impact on risk and the result is consistent with the notion that more liquid banks are less risky. Deposit ratio has a negative impact on risk which indicates that an increase in 
deposit ratio leads to a decrease in risk. Real growth in GDP has a positive impact on risk. It suggests that if real growth in GDP increases, the banks have more risktaking opportunities and hence take higher risk. Inflation has a negative impact on risk which denotes that during high inflation banks take lower level of risk. Lagged risk is negatively associated with the risk at significant level. The negative sign indicates that banks with higher risk in previous year may reduce their risk in current period.

From the adjusted R-square it can be concluded that $54.77 \%$ variation in risk (proxied by NPLTL) is explained by Model 1 and 37.36\% variation in risk (proxied by SROA) is explained by the Model 2. The $p$-value of Hausman test for Models 1 and 2 is 0.000 (significant at $1 \%$ level) indicating that risk and capital are simultaneously determined. Sargan test for Models 1 and 2 is not significant and null hypothesis that over identifications restrictions are valid cannot be rejected. Serial correlation test reject the null hypothesis of no serial correlation.

\section{Conclusion and Recommendations}

This study examines the relationships among bank size, regulatory capital ratios and risk-taking of commercial banks of Bangladesh. The empirical results show that there is a significant negative relationship between regulatory capital ratios and bank risk-taking. This result implies that capital regulation is effective in reducing risk of commercial banks in Bangladesh. These findings suggest that the objective of capital regulation is being met in Bangladesh; that is, risk of banks can be reduced by increasing capital ratios. Thus, one implication from our study is that bank risk-taking can be contained by increasing the capital requirements. Another implication specific to Bangladesh is that the supervisory authority in Bangladesh should set up the mechanism to ensure that banks meet the regulatory capital requirements to make banking industry as a whole sound.

The empirical results also show that bank size has a significant negative relationship with bank capital, while significant positive relationship with bank risk-taking. These results imply that larger banks hold lower amount of capital and take higher levels of risk. These findings suggest that special attention should be paid to large banks to increase their capital ratios and to decrease their risk-taking. To make banks safe, larger banks should have loss absorbing capacity beyond the minimum standards. This can be done by requiring larger banks to hold a buffer capital in addition to minimum capital requirements.

The empirical results also reveal that banks with more liquidity holds lower capital ratio and take lower level of risk. Focus should be given to different loan and advances as liquidity has negative impact to capital ratio. Under the capital regulation, commercial banks should allocate their resources and expand their businesses in a way that safety, liquidity and earning level are integrated to attain the continuous development of commercial banks in Bangladesh. Government 
should work on GDP and control inflation for the efficient functioning of the commercial banks in Bangladesh.

\section{Acknowledgement}

We acknowledge the support of the project of National Natural Science Foundation of China (NSFC) [Grant No. 71173077].

\section{References}

Afzal, A., and Mirza, N. (2012), "Size, Diversification and Risk: Preliminary Evidence from Commercial Banks in Pakistan". Pakistan Journal of Commerce and Social Science 6(2): 282296.

Aggarwal, R., and Jacques, K.T. (1998), "Assessing the Impact of Prompt Corrective Action on Bank Capital and Risk". FRBNY Economic Policy Review: 23-32. http://dx.doi.org/10.2139/ssrn.1024839

Altunbas, Y., Carbo, S., Gardener, E.P.M., and Molyneux, P. (2007), "Examining the Relationships between Capital, Risk and Efficiency in European Banking". European Financial Management 13(1): 49-70. http://dx.doi.org/10.1111/j.1468-036X.2006.00285.x

Ashraf, B.N., Arshad, S., Rahman, M.M., Kamal, M.A., Khan, K., (2015), "Regulatory hypothesis and bank dividend payouts: Empirical evidence from Italian banking sector". Journal of Financial Engineering 2(1): 15. http://dx.doi.org/10.1142/S2345768615500099

Ashraf, B.N., and Zheng, C., (2015),"Shareholder protection, creditor rights and bank dividend policies". China Finance Review International 5(2): 161 - 186. http://dx.doi.org/10.1108/CFRI-08-2014-0057

Avery, R.B., and Berger, A.N. (1991), "Risk-Based Capital and Deposit Insurance Reform". Journal of Banking and Finance 15: 847-874. http://dx.doi.org/10.1016/03784266(91)90103-S

Ayuso, J., Pérez, D., and Saurina, J. (2004), "Are Capital Buffers Pro-Cyclical? Evidence from Spanish Panel Data". Journal of Financial Intermediation 13(2): 249-64. http://dx.doi.org/10.1016/S1042-9573(03)00044-5

Berger, A.N. (1995), "The Relationship between Capital and Earnings in Banking". Journal of Money, Credit, and Banking 27: 432-456. http://dx.doi.org/10.2307/2077877

Blum, J. (1999), "Do Capital Adequacy Requirements Reduce Risk in Banking"? Journal of Banking and Finance 23: 755-771. http://dx.doi.org/10.1016/S0378-4266(98)00113-7

Boyd, J.H., Jagannathan, R., and Kwak, S. (2009), "What caused the current financial mess and what can we do about it"? Journal of investment Management 7: 1-17. http://dx.doi.org/10.2139/ssrn.1463064

Calem, P., and Rob, R. (1999), "The Impact of Capital-Based Regulation on Bank Risk-Taking". Journal of Financial Intermediation 8: 317-352. http://dx.doi.org/10.1006/jfin.1999.0276

Ediz, T., Michael, I., and Perraudin, W. (1998), "The Impact of Capital Requirements of U.K Bank's Behavior". Frbny Economic Policy Review: 15-23.

Furlong, F.T., and Keeley, M.C. (1989), "Capital Regulation and Bank Risk-taking: A Note". Journal of Banking and Finance 13(6): 883-891. http://dx.doi.org/10.1016/03784266(89)90008-3 
González, F. (2004), "Bank regulation and risk-taking incentives: An international comparison of bank risk". Journal of Banking and Finance 29: 1153-1184.

http://dx.doi.org/10.1016/j.jbankfin.2004.05.029

Hussain, M.E., and Hassan, M.K. (2005), "Basel Capital Requirements and Bank Credit Risk Taking In Developing Countries". Department of Economic and Finance Working Papers, 1991-2006, Paper 34.

Houston, J.F., Lin, C., Lin, P., and Ma, Y. (2010). "Creditor rights, information sharing, and bank risk taking". Journal of Financial Economics 96: 485-512.

http://dx.doi.org/10.1016/j.jfineco.2010.02.008

Iwatsubo, K. (2007), "Bank capital shocks and portfolio risk: Evidence from Japan". Japan and the World Economy 19: 166-186. http://dx.doi.org/10.1016/j.japwor.2005.09.001

Jacques, K., and Nigro, P. (1997), "Risk-Based Capital, Portfolio Risk, and Bank Capital: A Simultaneous Equation Approach". Journal of Economics and Business 49: 533-547. http://dx.doi.org/10.1016/S0148-6195(97)00038-6

Jiménez, G., and Saurina, J. (2006), "Credit Cycles, Credit Risk, and Prudential Regulation". International Journal of Central Banking 2(2): 65-98.

Jokipii, T., and Milne, A. (2011), "Bank capital buffer and risk adjustment decisions". Journal of Financial Stability 7: 165-178. http://dx.doi.org/10.1016/j.jfs.2010.02.002

Kanagaretnam, K., Lim, C.Y., and Lobo, G.J., (2014). "Influence of National Culture on Accounting Conservatism and Risk-Taking in the Banking Industry". Accounting Review 89: 1115-1149. http://dx.doi.org/10.2139/ssrn.2319548

Kim, D., and Santomero, A.M. (1988), "Risk in Banking and Capital Regulation". The Journal of Finance 43(5): 1219-1233. http://dx.doi.org/10.1111/j.1540-6261.1988.tb03966.x

Klomp, J., and Haan, J. (2012), "Banking risk and regulation: Does one size fit all"? Journal of Banking \& Finance 36: 3197-3212. http://dx.doi.org/10.1016/j.jbankfin.2011.10.006

Koehn, M., and Santomero, A.M. (1980), "Regulation of Bank Capital and Portfolio Risk". The Journal of Finance 35(5): 1235-1244. http://dx.doi.org/10.1111/j.1540-6261.1980.tb02206.x

Leaven, L., and Levine, R. (2009), "Bank governance, regulation and risk taking". Journal of Financial Economics 93: 259-275. http://dx.doi.org/10.3386/w14113

Repullo, R. (2002), "Capital requirements, Market Power, and Risk-Taking in Banking". $\begin{array}{llll}\text { Journal of Financial Intermediation 13(2): } & \text { 156-182. }\end{array}$ http://dx.doi.org/10.1016/j.jfi.2003.08.005

Rime, B. (2001), "Capital requirements and bank behavior: Empirical evidence for Switzerland". Journal of Banking \& Finance 25: 789-805. http://dx.doi.org/10.1016/S03784266(00)00105-9

Roy, P.V. (2008), "Capital Requirements and Bank Behavior in the Early 1990s: Cross-Country Evidence". International Journal of Central Banking 4(3): 29-60

Shrieves, R., and Dahl, D. (2003), "The relationship between risk and capital in commercial banks". Journal of Banking and Finance 16(2): 439-457. http://dx.doi.org/10.1016/03784266(92)90024-T

Silva, N. (2007), "Capital Regulation and Bank Risk Taking: Completing Blum's Picture". Central Bank of Chile Working Papers, No. 416. 
Walter, I. (2009), "The new case for functional separation in wholesale financial service". New York University Working Paper.

Zheng, C. and Ashraf, B.N. (2014), "National culture and dividend policy: international evidence from banking". Journal of Behavioral and Experimental Finance 3: 22-40. http://dx.doi.org/10.1016/j.jbef.2014.07.002

Zhang, J., Jiang, C., Qu, B., and Wang, P. (2013), "Market concentration, risk-taking, and bank performance: Evidence from emerging economies". International Review of Financial Analysis 30: 149-157. http://dx.doi.org/10.1016/j.irfa.2013.07.016

Zhang, Z., Wu, J., and Liu, Q. (2008), "Impacts of Capital Adequacy Regulation on Risk-taking Behaviors of Banking". Systems Engineering- Theory \& Practice 28(8): 183-189. http://dx.doi.org/10.1016/S1874-8651(09)60035-1 